\title{
Low-dose plasmid DNA treatment increases plasma vasopressin and regulates blood pressure in experimental endotoxemia
}

\author{
Thiago Malardo ${ }^{1}$, Marcelo E Batalhão², Ademilson Panunto-Castelo ${ }^{3}$, Luciana P Almeida ${ }^{1}$, Everton Padilha',
} Isabela C Fontoura', Célio L Silva', Evelin C Carnio ${ }^{2}$ and Arlete AM Coelho-Castelo ${ }^{1 *}$

\begin{abstract}
Background: Although plasmid DNA encoding an antigen from pathogens or tumor cells has been widely studied as vaccine, the use of plasmid vector (without insert) as therapeutic agent requires further investigation.

Results: Here, we showed that plasmid DNA (pcDNA3) at low doses inhibits the production of IL-6 and TNF-a by lipopolysaccharide (LPS)-stimulated macrophage cell line J774. These findings led us to evaluate whether plasmid DNA could act as an anti-inflammatory agent in a Wistar rat endotoxemia model. Rats injected simultaneously with $1.5 \mathrm{mg} / \mathrm{kg}$ of LPS and 10 or $20 \mathrm{\mu g}$ of plasmid DNA had a remarkable attenuation of mean arterial blood pressure (MAP) drop at 2 hours after treatment when compared with rats injected with LPS only. The beneficial effect of the plasmid DNA on MAP was associated with decreased expression of IL-6 in liver and increased concentration of plasma vasopressin (AVP), a known vasoconstrictor that has been investigated in hemorrhagic shock management. No difference was observed in relation to nitric oxide (NO) production.
\end{abstract}

Conclusion: Our results demonstrate for the first time that plasmid DNA vector at low doses presents anti-inflammatory property and constitutes a novel approach with therapeutic potential in inflammatory diseases.

Keywords: Endotoxemic shock, Interleukin-6, Naked pcDNA3

\section{Background}

Plasmid DNA has been successfully used as preventive or therapeutic DNA vaccines in experimental models of viral, bacterial or parasitic diseases [1]. Such vaccines are composed of an antigen-encoding gene, in which its expression is regulated by a strong mammalian promoter expressed on a plasmid backbone of bacterial DNA [2-4]. Although there has been a reasonable excitement about DNA vaccines because of protection induced by strong $\mathrm{T}$ helper 1 responses, it has become apparent that these attained responses in non-human primates and humans are weaker than those in mice, probably because of questions related to dosage and CpG stimulations [5,6]. This aspect is an important issue to improve DNA vaccines. We have previously studied DNA vaccine biodistribution

\footnotetext{
* Correspondence: arlete@fmrp.usp.br

1 Department of Biochemistry and Immunology, School of Medicine of Ribeirao Preto, University of São Paulo, Ribeirao Preto SP 14049-900, Brazil Full list of author information is available at the end of the article
}

[7] and also showed that naked plasmid DNA at low doses inhibits antigen presentation to T cells [8]. Besides, preliminary data from our group has suggested that naked plasmid DNA at low doses has anti-inflammatory properties.

In the last few years, Gram-negative bacteria have re-emerged as one of the most important pathogens that induce blood stream infections [9]. These bloodborne bacteria can produce serious systemic reactions, known as severe sepsis and shock septic, which are associated with marked hemodynamic alterations, such as hypotension, abnormal perfusion of organs and tissues, decreased systemic vascular resistance and increased heart rate (HR) [10]. Patients with severe sepsis have frequently presented dysfunction/failure of at least one organ and, in about $30 \%$ of the cases, multiple organ dysfunction syndrome (MODS) [11].

In Gram-negative sepsis, hemodynamic instability in response to infection is due to excessive production of

\section{Biomed Central}


inflammatory mediators by endotoxin-activated inflammatory cells [12]. Endotoxins, such as outer membrane wall component lipopolysaccharide (LPS) from Gramnegative bacteria [13], are responsible for direct activation of cells and indirect inflammatory cascade, leading to the production of tumor necrosis factor- $\alpha$ (TNF- $\alpha$, interleukin (IL-) 1, IL- 6 and IL-8 by macrophages and monocytes [14-17]. The production of these proinflammatory cytokines is dependent on LPS-binding protein, receptors CD14 and Toll-like receptor (TLR) 4 [18] and following the intracellular activation cascade, which triggers the nuclear translocation of nuclear factor- $\mathrm{kB}(\mathrm{NF}-\mathrm{kB})$ and following activation of cytokines gene promoters [19].

IL-6, TNF- $\alpha$ and other inflammatory cytokines are of fundamental importance in sepsis development by mediating some biological responses, such as elevated production of nitric oxide (NO) by macrophages [20]. NO is a highly diffusible gas that is produced through a nitric oxide synthase (NOS)-catalyzed oxidation of L-arginine to L-citrulline. Although NOS presents non-inducible isoforms, it is the inducible NOS (iNOS) isoform, present in activated leukocytes, that contributes to vascular hyporesponsiveness and hemodynamic alterations associated with sepsis [21]. Moreover, iNOS-deficient mice are resistant to LPS-induced death, indicating a critical role of NO in sepsis development [22].

As the major symptoms of sepsis are related to proinflammatory and coagulant mediators, many studies have focused on molecules that could modulate these mediators. However, treatment of severe sepsis and septic shock with corticosteroids, the most powerful anti-inflammatory agents, has been controversial [23]. Besides, clinical experience with mediator-specific anti-inflammatory agents in sepsis has been disappointing [24]. The fact that preliminary data from our group suggested that naked plasmid DNA at low doses might have anti-inflammatory properties motivated us to evaluate plasmid DNA in experimental endotoxemia. Here, we demonstrated that low dose of plasmid DNA can decrease inflammatory cytokines and the initial hypotension noticed in endotoxemia, opening new perspectives for the treatment of inflammatory diseases.

\section{Methods}

\section{Ethical approval}

All experiments were performed in accordance with institutional ethical guidelines of the Animal Care Committee of the University. Approval was granted by the Committee of the University of Sao Paulo at Ribeirão Preto School of Medicine (CETEA-FMRP-USP).

\section{Rats and reagents}

Experiments were performed on adult male Wistar rats weighing $250-300 \mathrm{~g}$ at the time of surgery. The animals were maintained under standard conditions with controlled temperature $\left(25.0 \pm 2^{\circ} \mathrm{C}\right)$ and exposed to a daily 12:12 $\mathrm{h}$ light dark cycle, in the animal house of the University of São Paulo at Ribeirão Preto College of Nursing, Ribeirão Preto, SP, Brazil.

RPMI 1640 medium, Hepes, fetal calf serum (FCS), TRIzol and plasmid pcDNA3 were obtained from Invitrogen (Carlsbad, CA, USA), and L-glutamine, 2mercaptoethanol, penicillin, streptomycin, lipopolysaccharide (LPS) from Escherichia coli serotype 0111:B4, dexamethasone and 2,2,2-tribromoethanol, sodium nitrate were obtained from Sigma-Aldrich Co. (St. Louis, MO, USA). Cell culture plates were purchased from Corning Inc. (Corning, NY, USA). Recombinant mouse IL-6, capture and biotinylated monoclonal anti-IL-6 (clones MP5-20F3 and MP5-32C11) and an OptEIA mouse TNF- $\alpha$ (Mono/Mono) set were purchased from BD Biosciences (San Jose, CA, USA). The forward and reverse primers of IL-6 (f: TCCTACCCCAACTTCC AATGCTC and $r$ : TTGGATGGTCTTGGTCCTTA GCC), TNF- $\alpha$ (f: AAATGGGCTCCCTCTCATCAGTTC and $r$ : TCTGCTTGGTGGTTTGCTACGAC) and $\beta$-actin (f: AAGTCCCTCACCCTCCCAAAAG and r: AAGCAAT GCTGTCACCTTCCC) were purchased from Invitrogen (São Paulo, Brazil).

\section{Plasmid DNA preparation}

pcDNA3 was propagated in Escherichia coli strain DH5 $\alpha$ and large-scale preparations of plasmid DNA were carried out using the EndoFree Plasmid Giga Kit (Qiagen, Ltd., Crawley, UK) according to the manufacturer's instructions. Spectrophotometric analysis revealed 260/280 $\mathrm{nm}$ ratios $\geq 1.80$. The purity of DNA preparations was confirmed on a $1 \%$ agarose gel. Samples of plasmid in the doses described below were administered in normal rats and we observed no changes in body temperature, suggesting absence or very low concentration of endotoxin.

\section{Cell line culture}

The macrophage cell line J774 $\left(5 \times 10^{5}\right.$ cells $\left./ \mathrm{mL}\right)$ was suspended in complete RPMI medium (RPMI 1640 containing $2 \mathrm{mM}$ L-glutamine, $50 \mu \mathrm{M}$ 2-mercaptoethanol, $100 \mathrm{units} / \mathrm{ml}$ penicillin, $100 \mu \mathrm{g} / \mathrm{mL}$ streptomycin and $5 \%$ heat-inactivated FCS), seeded in 24-well cell culture plates, $1 \mathrm{~mL}$ per well, and stimulated with plasmid pcDNA3 at the concentration ranging from 1 to $100 \mu \mathrm{g} / \mathrm{mL}$. In the inhibition experiments, J774 cells were simultaneously stimulated with $500 \mathrm{ng}$ of LPS and pcDNA3 at the concentration of 3,5 or $10 \mu \mathrm{g} / \mathrm{mL}$. LPS (500 ng) was also used as the positive control. After incubation at $37^{\circ} \mathrm{C}$ in a humidified $5 \% \mathrm{CO}_{2}$ atmosphere for $48 \mathrm{~h}$, the supernatants were harvested and the concentrations of IL- 6 and TNF- $\alpha$ were determined by ELISA, according to recommendations obtained from BD Biosciences. 


\section{Experimental design}

Rats were submitted to general anesthesia with intraperitoneal injection of 2.5\% 2,2,2-tribromoethanol $(10 \mathrm{~mL} / \mathrm{kg}$ body weight) and implanted with a polyethylene catheter in the femoral artery for direct blood pressure recording and in the jugular vein for intravenous (i.v.) drug administration. The animals were injected i.v. by bolus injection with $1.5 \mathrm{mg} \mathrm{LPS} / \mathrm{kg}$ body weight in a final volume of $0.5 \mathrm{~mL}$ of pyrogen-free sterile physiological saline $(0.15 \mathrm{M}$ $\mathrm{NaCl}$ ). Experimental time "zero" was determined as the moment when LPS was injected. Control rats were injected i.v. with $0.5 \mathrm{~mL}$ sterile saline.

In a separate set of experiments, rats received an i.v. injection of 5,10 or $20 \mu \mathrm{g}$ plasmid DNA in a final volume of $0.5 \mathrm{~mL}$ physiological saline. Control animals were injected with the same volume of saline. Two minutes later, animals were injected with LPS as described above.

Mean arterial blood pressure (MAP) and HR of anaesthetized freely moving rats were recorded using a polygraph (Grass P122), connected to a pressure transducer (Grass P23XL-1) and using the software PolyView (Astro-Med, West Warwick, RI, USA), over a period of 4-6 h after LPS or saline i.v. injection. The rats were decapitated 2, 4 and $6 \mathrm{~h}$ after LPS or saline administration. Blood samples were collected into chilled heparinized plastic tubes, centrifuged for $20 \mathrm{~min}$ at $2000 \times \mathrm{g}$ at $4^{\circ} \mathrm{C}$. Plasma samples were stored at $-70^{\circ} \mathrm{C}$ before dosage. Liver samples were excised and frozen in liquid nitrogen and stored at $-70^{\circ} \mathrm{C}$ until processing.

\section{Plasma NO and arginine vasopressin (AVP) dosage}

On the day of the assay, plasma samples were thawed and deproteinized with $95 \%$ ethanol (at $4^{\circ} \mathrm{C}$ ) for $30 \mathrm{~min}$, subsequently centrifuged, and the supernatant was used for measurement of nitrate according to the $\mathrm{NO}$ /ozone chemiluminescence technique [25], using a Sievers NO Analyzer 280 (GE Analytical Instrument, Boulder, CO, USA). Sodium nitrate was used as standard reference. AVP extracted from $0.7-1.5 \mathrm{~mL}$ of plasma using acetone and petroleum ether was dried and stored at $-20^{\circ} \mathrm{C}$ until radioimmunoassay measurements were performed as previously described [26].

\section{Real-time reverse transcription polymerase chain reaction (RT-PCR)}

Total RNA from liver homogenized manually under liquid nitrogen with a mortar and pestle was extracted using TRIzol. Quantification of RNA was carried out on a NanoDrop ND1000 spectrophotometer (Fisher Thermo, Wilmington, USA) and its concentration adjusted to 0.25 $\mu \mathrm{g} / \mu \mathrm{L}$ using RNase free water. Reverse transcription (RT) was performed using the Rotor-Gene 6000 Real-Time PCR machine (Corbett Life Science, Mortlake, Australia).
Gene expression was determined in mRNA as previously reported [27], using primers described above.

\section{Data analysis}

Results are expressed as means \pm standard deviation. Statistical determinations of the difference between means of experimental groups were performed using one-way analysis of variance (analysis of variance) followed by the Tukey multiple comparisons test. Differences that provided $p<0.05$ were considered to be statistically significant.

\section{Results}

Low dose of plasmid DNA inhibits production of IL- 6 and TNF- $a$ by LPS-stimulated macrophages

To evaluate the production of inflammatory cytokines in vitro by plasmid DNA-stimulated macrophages, we incubated J774 cells with plasmid pcDNA3. Although plasmid induced the production of IL-6 in a dosedependent manner (Figure 1A), we observed that pcDNA3 in the concentration of $10 \mu \mathrm{g} / \mathrm{mL}$ led to production of low concentrations of IL-6 even when LPS $(0.5 \mu \mathrm{g} / \mathrm{mL})$ was simultaneously used in the stimulation of the cells (Figure 1B). This suppressive effect of $10 \mu \mathrm{g} / \mathrm{mL}$ of plasmid on production of IL-6 by LPSstimulated macrophage was surprising and remarkable, since there was a $99 \%$ reduction of its production when compared with cells cultured with LPS only or LPS and plasmid at the concentration of 3 or $5 \mu \mathrm{g} / \mathrm{mL}$ (Figure 1B). TNF- $\alpha$ production by LPS-stimulated J774 cells was also significantly suppressed with $10 \mu \mathrm{g} / \mathrm{mL}$ of pcDNA3 (Figure 1C).

\section{Low dose of plasmid DNA attenuates the LPS effect on the experimental endotoxemia}

Since plasmids was found to decrease in vitro production of TNF- $\alpha$ and IL- 6 by LPS-stimulated macrophage cell line and these cytokines play a key role in the inflammatory process, we evaluate if low doses of plasmid could have a beneficial effect in vivo in an endotoxemia model. To validate our experimental model, first we determined the MAP, HR and plasma concentration of NO and AVP in LPS-injected rats. As expected, the animals injected with LPS had a significant decrease in MAP and increase in HR, plasma nitrate and AVP concentrations as compared to control rats (Figure 2). When low doses of plasmid DNA were injected almost simultaneously (2 minutes before) with LPS, we observed that the administration of 10 or $20 \mu \mathrm{g}$ of plasmid significantly attenuated the MAP drop (Figure 2B and C). The plasmid treatment did not have considerable effect on the alterations of HR and body temperature induced by LPS (Figure 2D-I).

To explain the mechanism involved in the plasmidinduced attenuation of MAP drop in LPS-stimulated 


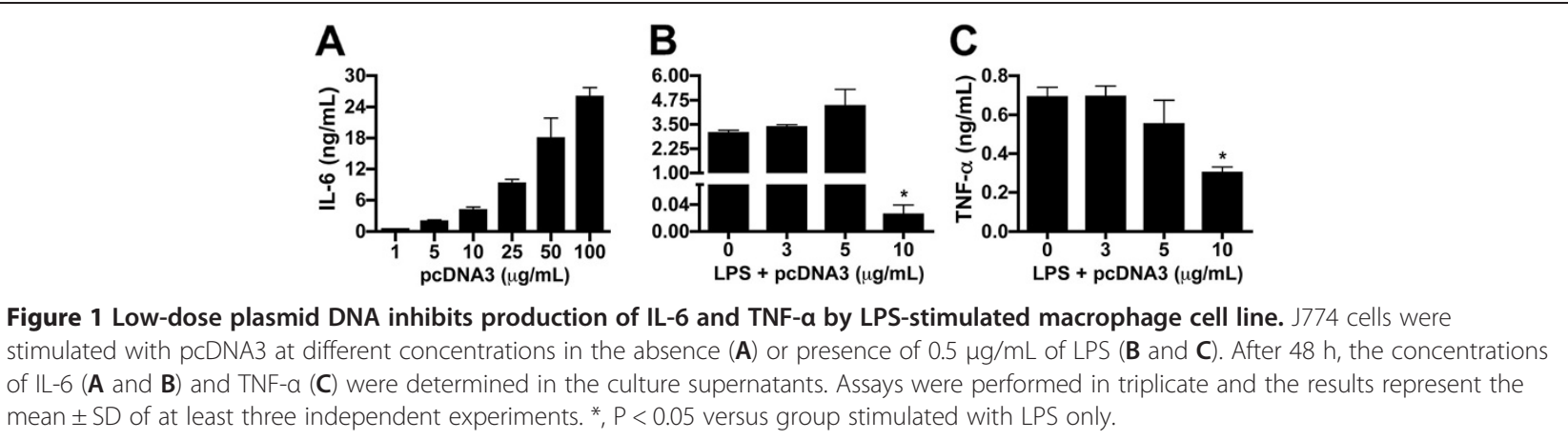

rats, we determined the gene expression of liver IL-6 and TNF- $\alpha$ and plasma concentration of AVP and NO, key mediators in endotoxemia. Similar to in vitro experiments, low doses of plasmid DNA (5 and $10 \mu \mathrm{g}$ ) induced a significant decrease of TNF- $\alpha$ and IL- 6 message in the livers of LPS-injected rats. IL- 6 was diminished at 2 hours after LPS injection when compared with the rats administered with LPS only (Figure 3), whereas no

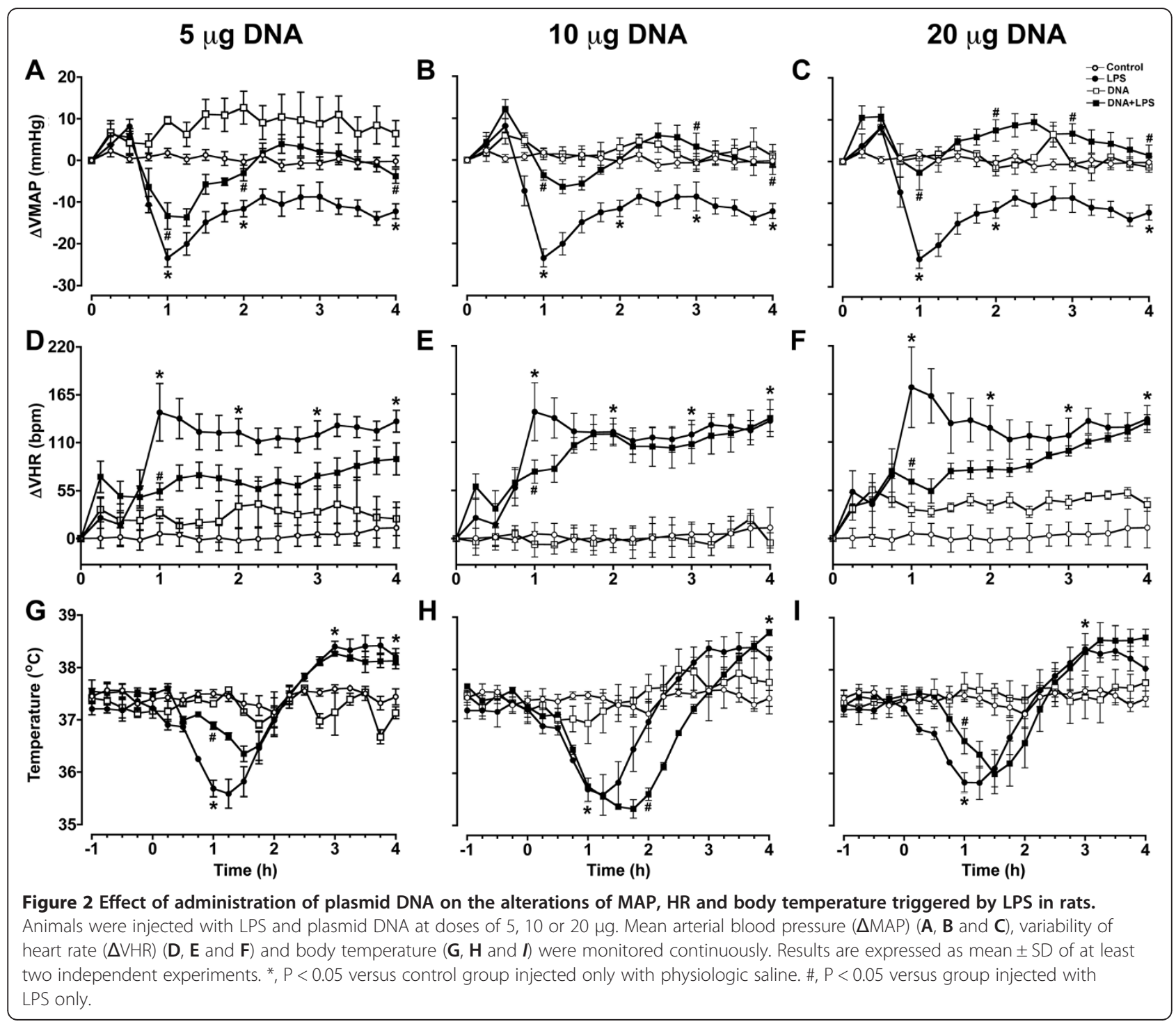



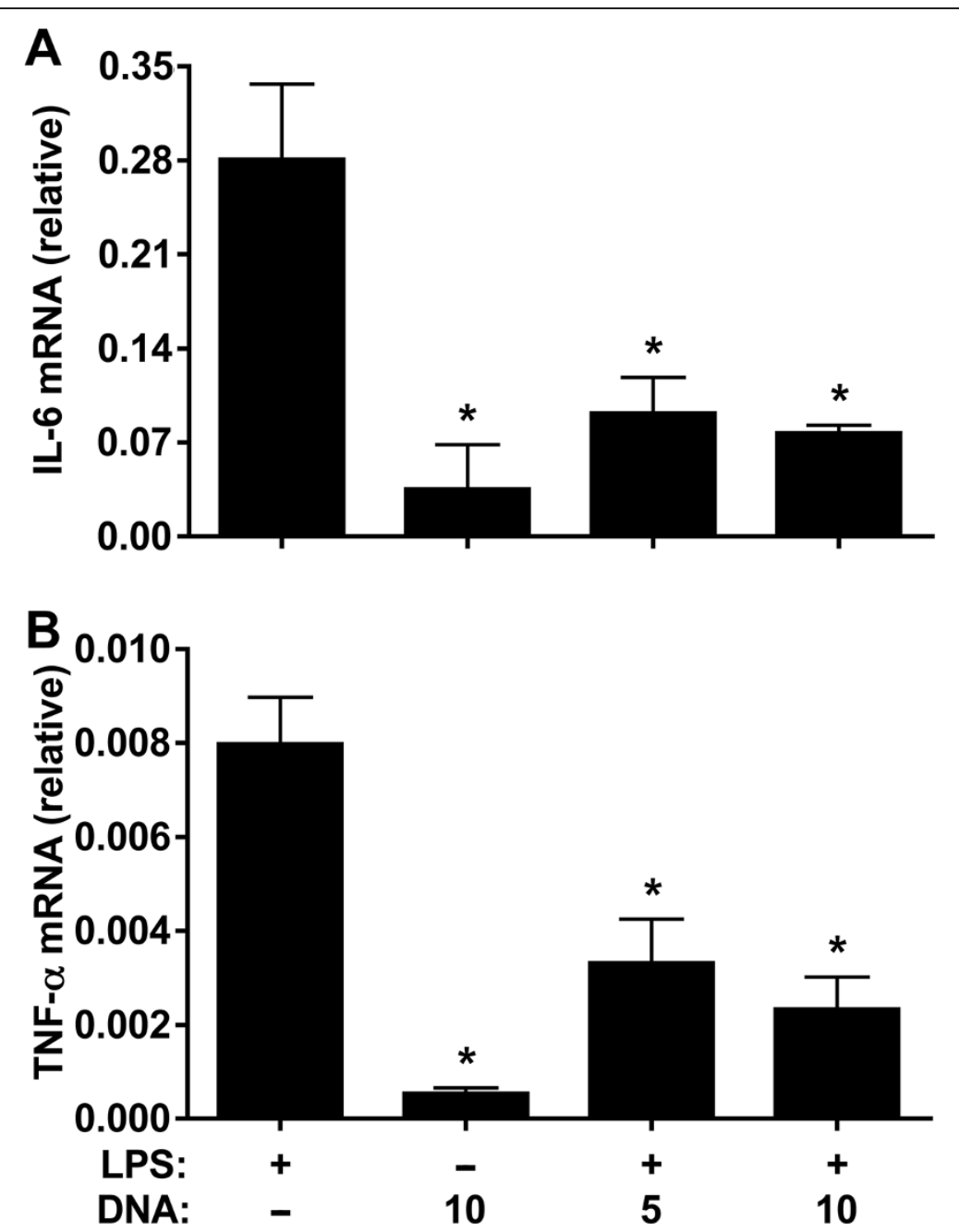

Figure 3 Administration of DNA in rats injected with LPS decreases liver expression of IL-6 and TNF-a. Animals were injected with LPS and plasmid DNA at doses of 5 or $10 \mu \mathrm{g}$. At 2 (A) or 4 (B) hours after injection of LPS, relative amounts of mRNA for IL-6 (A) and TNF-a (B) from liver were determined. Results are expressed as mean \pm SD of at least two independent experiments. ${ }^{*}, \mathrm{P}<0.05$ versus control group injected with LPS only.

significant difference was detected at 4 hours after LPS injection (data not shown). In contrast, low doses of plasmid DNA induced a significant reduction in the TNF- $\alpha$ at 4 hours of experiment, but not at 2 hours, when compared with the group treated with LPS only (Figure 3). As the fall in MAP occurs in the first two hours after injection of LPS, we suggested that the decrease of IL-6 may be important in reducing the pressure drop observed in animals treated with plasmid DNA. Like IL-6, two hours after LPS administration, we observed that all tested dose of plasmid DNA significantly enhanced the LPS effect on AVP production, whereas only the doses of 10 and $20 \mu \mathrm{g}$ of plasmid led to a significant increase in NO (Figure 4). Interestingly, the concentrations of AVP were low after $4 \mathrm{~h}$ of LPS injection, whereas high concentrations of NO were maintained (Figure 4).

\section{Discussion}

In this research, we demonstrated for the first time that a low dose of plasmid DNA vector induces the production of low concentration of inflammatory cytokine IL-6 and TNF- $\alpha$ by in vitro LPS-stimulated macrophages. The novelty of this contribution lies in the fact that we evaluated this inflammatory suppression by a noncoding plasmid DNA in an endotoxemia model in rats and obtained a remarkable attenuation in the drop of MAP.

Since the sharp fall in MAP in case of endotoxemia can be a life-threatening situation, the maintenance of MAP is one of the major concerns in its treatment [28]. Our data demonstrated that plasmid DNA, mainly at doses of 10 and $20 \mu \mathrm{g}$, when administered concomitantly with LPS in rats, significantly prevented the drop in MAP within the first hour of the experiment. This 

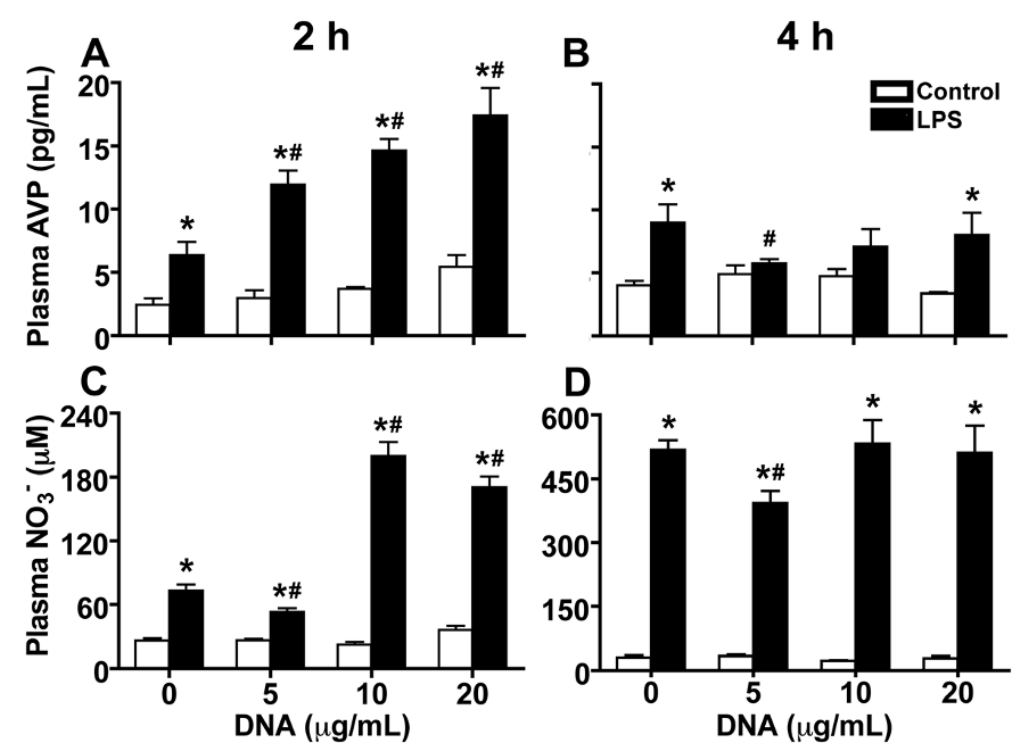

Figure 4 Effect of plasmid DNA on plasma concentration of $\mathrm{NO}_{3}^{-}$and AVP in LPS-injected rats. Animals were injected with LPS and plasmid DNA at doses of 5, 10 or $20 \mu \mathrm{g}$. At 2 (A and $\mathbf{C}$ ) and 4 (B and $\mathbf{D})$ hours after injection of LPS, blood was collected and the concentration of plasma AVP (A and $\mathbf{B})$ and $\mathrm{NO}_{3}^{-}(\mathrm{C}$ and $\mathrm{D})$ was determined. Results are expressed as mean $\pm \mathrm{SD}$ of at least two independent experiments. ${ }^{*}, \mathrm{P}$ $<0.05$ versus control group injected only with physiologic saline. \#, P $<0.05$ versus group injected with LPS only.

stabilization of MAP was maintained until the fourth hour after LPS injection. Although we cannot exclude that there may have been in vivo direct interaction between plasmid and LPS, this seems unlikely because this interaction should induce an inhibition of all parameters analyzed in a dose response manner. Our in vivo experiments demonstrated that $5 \mu \mathrm{g}$ of plasmid was able to produce a decrease of the effect of LPS on the temperature of rats, but not on the $\triangle \mathrm{VHR}$ and $\triangle$ VMAP, when compared with the doses of 10 and $20 \mu \mathrm{g}$. In contrast, 10 and $20 \mu \mathrm{g}$ of plasmid diminished the effect of LPS on the $\triangle$ VHR and $\triangle$ VMAP, but not on temperature.

AVP and NO have been described as important mediators in septic shock [29-32]. AVP is a hormone that raises blood pressure by regulating vascular water balance and inducing vasoconstriction [33]. The plasma concentration of AVP is increased in the first and second hour after administration of LPS in rats [34], as seen in our control 2 hours after LPS injection. More importantly, all tested doses of plasmid DNA were able to further increase the concentration of plasma AVP in LPS-injected rats at the second hour of experiment, in a dose dependent manner. Though plasmid DNA was responsible for the increase of AVP in the first 2 hours, its effect was indirect, since rats injected with only plasmid DNA did not have increased AVP concentrations. This increase in plasma AVP concentrations suggests it could be responsible for recovering MAP.

Concerning to NO, although some studies have demonstrated that specific iNOS inhibitors can reduce the MAP drop in animal models [34-36], this has not been observed in septic patients [37,38]. Even so, we analyzed NO because it is considered one of the major factors responsible for refractory hypotension in sepsis, has its concentration increased after LPS injection [39], and appears to play a key inhibitory role in AVP released during endotoxemia, leading to hypotension [34]. Apparently, NO over-production from endotoxin/cytokinesinduced iNOS mediates a vasodilatation difficult to revert with vasoconstrictors [40]. In our experiments, NO level was decreased until the fourth hour of the experiment only in the group administered with LPS and treated with $5 \mu \mathrm{g}$ of plasmid DNA. Interestingly, $5 \mu \mathrm{g}$ of plasmid DNA was not able to maintain the MAP in these rats. In contrast, 10 and $20 \mu \mathrm{g}$ of plasmid DNA, which best stabilized the MAP in the second hour after LPS administration, were the doses that significantly increased the concentrations of $\mathrm{NO}$ when compared to rats injected with LPS only. Therefore, even with high production of NO, the LPS-injected rats treated with plasmid DNA did not show a drop in MAP.

Given that physiological changes in sepsis are in part caused by high concentrations of inflammatory mediators, it is reasonable to suppose that, among the treatments that have been investigated in sepsis, emphasis has been given to the inhibition of these mediators [41]. In our experiment in vitro, plasmid DNA significantly decreased the production of IL- 6 and TNF- $\alpha$ by LPS-stimulated macrophage cell line J774. The effect of plasmid DNA on LPS-stimulated J774 cells was more pronounced on the IL-6 than TNF- $\alpha$, i.e., 99\% 
reduction for IL- 6 and $56 \%$ for TNF- $\alpha$ when compared with macrophages stimulated with LPS only. Similar results were obtained when our in vitro experiments were done with another plasmid (pVAX), suggesting that the anti-inflammatory property does not appear to be restricted to the pcDNA3 (data not shown). Because studies have indicated that Kupffer cells promote a significant role in the production of proinflammatory cytokines, such as TNF- $\alpha$, IL-1 and IL-6, after stimulation with LPS [42-44], we evaluated IL-6 and TNF- $\alpha$ messages from liver. Interestingly, the results of real time RT-PCR showed that the in vivo gene expression of IL-6, but not TNF- $\alpha$, was decreased significantly at 2 hours after plasmid DNA and LPS injection when compared with injection of LPS only, suggesting that IL-6 contributes to the stabilization of MAP. Such stabilization was not attributed to the TNF- $\alpha$ as it was decreased only at 4 hours after plasmid DNA and LPS injection. The role of IL-6 in murine sepsis has been somewhat controversial, since data from the literature are conflicting in relation to survival of IL-6 knockout mice subject to cecal ligation and puncture [45-47]. Nevertheless, IL-6 has pointed out as an important cytokine in sepsis with pro- and anti-inflammatory effects $[48,49]$, regardless of whether it is a disease biomarker or contributes to severity of sepsis [50]. More importantly, IL-6 appears to be one of the best predictors to determine MODS, sepsis severity and mortality in both animal models [51,52] and human [49,53-56]. The former data from the literature supported our hypothesis that low expression of IL-6 induced by the plasmid DNA treatment was crucial to dampen the LPS-induced hypotension in rats.

AVP infusion has been suggested as an alternative therapy for septic shock patients that are refractory to usual vasopressor therapy [29]. This therapy can be justified because plasma AVP concentrations in septic patients are maintained close to physiological level, although a lower blood pressure is noticeable [57]. Because plasma concentrations of AVP might be inappropriately low in septic shock [57] and, as seen in this study, plasmid DNA can increase concentration of AVP and improve MAP, we suggested that plasmid DNA constitutes a novel approach with therapeutic potential in sepsis that may have clinical applications.

\section{Conclusion}

We demonstrated that rats injected concomitantly with LPS and small doses of plasmid DNA had a remarkable attenuation in the drop of blood pressure at 2 hours after treatment when compared with rats injected with LPS only. The beneficial effect of plasmid DNA on blood pressure was associated with decreased expression of IL-6 in liver and increased plasma vasopressin concentrations.
Our results demonstrate for the first time that plasmid DNA vector can be anti-inflammatory and constitute a novel approach with therapeutic potential in inflammatory diseases.

\section{Competing interest}

The authors declare that they have no competing interests.

\section{Authors' contributions}

TM, MEB, EP, ICF and LPA participated in the design of the study and experiments. AAMC-C, AP-C, CLS and ECC conceived the study and participated in its design and coordination. AP-C and AAMC-C wrote the paper. All authors read and approved the final manuscript.

\section{Acknowledgments}

We thank Dr. José Antunes Rodrigues from School of Medicine of Ribeirão Preto, University of São Paulo, for vasopressin dosage. We are grateful to Mrs. Ana Flavia Gembre, Ana Paula Masson and Izaíra Brandão for technical assistance. This work was funded by the São Paulo Research Foundation (FAPESP - Grant number 2006/03987-7).

\section{Author details}

'Department of Biochemistry and Immunology, School of Medicine of Ribeirao Preto, University of São Paulo, Ribeirao Preto SP 14049-900, Brazil. ${ }^{2}$ Department of General and Specialized Nursing, College of Nursing of Ribeirao Preto, University of São Paulo, Ribeirao Preto SP 14040-902, Brazil. ${ }^{3}$ Department of Biology, School of Philosophy, Sciences and Literature of Ribeirao Preto, University of Sao Paulo, Ribeirao Preto SP 14040-901, Brazil.

Received: 31 March 2012 Accepted: 31 October 2012

Published: 8 November 2012

\section{References}

1. Williams JA, Carnes $A E$, Hodgson CP: Plasmid DNA vaccine vector design: impact on efficacy, safety and upstream production. Biotechnol Adv 2009, 27(4):353-370

2. Sato $Y$, Roman $M$, Tighe $H$, Lee $D$, Corr M, Nguyen MD, Silverman GJ, Lotz M, Carson DA, Raz E: Immunostimulatory DNA sequences necessary for effective intradermal gene immunization. Science 1996, 273(5273):352-354.

3. Ulmer JB, Donnelly JJ, Parker SE, Rhodes GH, Felgner PL, Dwarki VJ, Gromkowski SH, Deck RR, DeWitt CM, Friedman A, et al: Heterologous protection against influenza by injection of DNA encoding a viral protein. Science 1993, 259(5102):1745-1749.

4. Wolff JA, Malone RW, Williams P, Chong W, Acsadi G, Jani A, Felgner PL: Direct gene transfer into mouse muscle in vivo. Science 1990, 247(4949 Pt 1):1465-1468.

5. Abdulhaqq SA, Weiner DB: DNA vaccines: developing new strategies to enhance immune responses. Immunol Res 2008, 42(1-3):219-232.

6. Gurunathan S, Wu CY, Freidag BL, Seder RA: DNA vaccines: a key for inducing long-term cellular immunity. Curr Opin Immunol 2000, 12(4):442-447.

7. Coelho-Castelo AA, Trombone AP, Rosada RS, Santos RR Jr, Bonato VL, Sartori A, Silva CL: Tissue distribution of a plasmid DNA encoding Hsp65 gene is dependent on the dose administered through intramuscular delivery. Genet Vaccines Ther 2006, 4:1

8. Trombone $\mathrm{AP}$, Silva $\mathrm{CL}$, Lima KM, Oliver $\mathrm{C}$, Jamur MC, Prescott $\mathrm{AR}$, Coelho-Castelo AA: Endocytosis of DNA-Hsp65 alters the pH of the late endosome/lysosome and interferes with antigen presentation. PLOS One 2007, 2(9):e923.

9. Muñoz P, Cruz AF, Rodriguez-Creixems M, Bouza E: Gram-negative bloodstream infections. Int J Antimicrob Agents 2008, 32(Suppl 1):S10-S14.

10. Crowley SR: The pathogenesis of septic shock. Heart Lung 1996, 25(2):124-134. quiz 135-126.

11. Davies MG, Hagen PO: Systemic inflammatory response syndrome. Br J Surg 1997, 84(7):920-935.

12. Bone RC: The pathogenesis of sepsis. Ann Intern Med 1991, 115(6):457-469.

13. Maliszewski CR: CD14 and immune response to lipopolysaccharide. Science 1991, 252(5010):1321-1322. 
14. Fong Y, Moldawer LL, Shires GT, Lowry SF: The biologic characteristics of cytokines and their implication in surgical injury. Surg Gynecol Obstet 1990, 170(4):363-378.

15. Lowry SF: Cytokine mediators of immunity and inflammation. Arch Surg 1993, 128(11):1235-1241.

16. Moldawer LL: Biology of proinflammatory cytokines and their antagonists. Crit Care Med 1994, 22(7):S3-S7.

17. Thijs LG, Hack CE: Time course of cytokine levels in sepsis. Intensive Care Med 1995, 21(Suppl 2):S258-S263.

18. Cohen J: The immunopathogenesis of sepsis. Nature 2002, 420(6917):885-891.

19. Chow JC, Young DW, Golenbock DT, Christ WJ, Gusovsky F: Toll-like receptor-4 mediates lipopolysaccharide-induced signal transduction. J Biol Chem 1999, 274(16):10689-10692.

20. Bhatia M, He M, Zhang H, Moochhala S: Sepsis as a model of SIRS. Front Biosci 2009, 14:4703-4711.

21. Julou-Schaeffer G, Gray GA, Fleming I, Schott C, Parratt JR, Stoclet J-C: Activation of the L-arginine-nitric oxide pathway is involved in vascular hyporeactivity induced by endotoxin. J Cardiovasc Pharmacol 1991, 17(Suppl. 3):S207-S212.

22. Wei XQ, Charles IG, Smith A, Ure J, Feng GJ, Huang FP, Xu D, Muller W Moncada S, Liew FY: Altered immune responses in mice lacking inducible nitric oxide synthase. Nature 1995, 375(6530):408-411.

23. Sprung CL, Goodman S, Weiss YG: Steroid therapy of septic shock. Crit Care Clin 2009, 25(4):825-834. $x$

24. Marshall JC: Clinical trials of mediator-directed therapy in sepsis: what have we learned? Intensive Care Med 2000, 26(Suppl 1):S75-S83.

25. Archer S: Measurement of nitric oxide in biological models. FASEB J 1993, 7(2):349-360.

26. Elias LL, Antunes-Rodrigues J, Elias PC, Moreira AC: Effect of plasma osmolality on pituitary-adrenal responses to corticotropin-releasing hormone and atrial natriuretic peptide changes in central diabetes insipidus. J Clin Endocrinol Metab 1997, 82(4):1243-1247.

27. Peinnequin A, Mouret C, Birot O, Alonso A, Mathieu J, Clarencon D, Agay D, Chancerelle $Y$, Multon E: Rat pro-inflammatory cytokine and cytokine related mRNA quantification by real-time polymerase chain reaction using SYBR green. BMC Immunol 2004, 5:3.

28. Vincent $J$, Zhang H, Szabo C, Preiser JC: Effects of nitric oxide in septic shock. Am J Respir Crit Care Med 2000, 161(6):1781-1785.

29. Holmes $C L$, Patel BM, Russell JA, Walley KR: Physiology of vasopressin relevant to management of septic shock. Chest 2001, 120(3):989-1002.

30. Robertson GL, Shelton RL, Athar S: The osmoregulation of vasopressin. Kidney Int 1976, 10(1):25-37.

31. Titheradge MA: Nitric oxide in septic shock. Biochim Biophys Acta 1999, 1411(2-3):437-455.

32. Wilson MF, Brackett DJ, Hinshaw LB, Tompkins P, Archer LT, Benjamin BA: Vasopressin release during sepsis and septic shock in baboons and dogs. Surg Gynecol Obstet 1981, 153(6):869-872.

33. Treschan TA, Peters J: The vasopressin system: physiology and clinical strategies. Anesthesiology 2006, 105(3):599-612. quiz 639-540.

34. Giusti-Paiva A, De Castro M, Antunes-Rodrigues J, Carnio EC: Inducible nitric oxide synthase pathway in the central nervous system and vasopressin release during experimental septic shock. Crit Care Med 2002 30(6):1306-1310

35. Altavilla D, Squadrito F, Campo GM, Squadrito G, Arlotta M, Urna G, Sardella A, Quartarone C, Saitta A, Caputi AP: The lazaroid, U-74389G, inhibits inducible nitric oxide synthase activity, reverses vascular failure and protects against endotoxin shock. Eur J Pharmacol 1999, 369(1):49-55.

36. Rosselet A, Feihl F, Markert M, Gnaegi A, Perret C, Liaudet L: Selective iNOS inhibition is superior to norepinephrine in the treatment of rat endotoxic shock. Am J Respir Crit Care Med 1998, 157(1):162-170.

37. Grover R, Zaccardelli D, Colice G, Guntupalli K, Watson D, Vincent JL: An open-label dose escalation study of the nitric oxide synthase inhibitor, $\mathrm{N}(\mathrm{G})$-methyl-L-arginine hydrochloride (546C88), in patients with septic shock. Glaxo Wellcome International Septic Shock Study Group. Crit Care Med 1999, 27(5):913-922

38. Lopez A, Lorente JA, Steingrub J, Bakker J, McLuckie A, Willatts S, Brockway M, Anzueto A, Holzapfel L, Breen D, et al: Multiple-center, randomized, placebo-controlled, double-blind study of the nitric oxide synthase inhibitor 546C88: effect on survival in patients with septic shock. Crit Care Med 2004, 32(1):21-30.
39. Cauwels A, Brouckaert P: Nitrite regulation of shock. Cardiovasc Res 2011, 89(3):553-559.

40. Duma D, Silva-Santos JE, Assreuy J: Inhibition of glucocorticoid receptor binding by nitric oxide in endotoxemic rats. Crit Care Med 2004, 32(11):2304-2310.

41. Minnich DJ, Moldawer LL: Anti-cytokine and anti-inflammatory therapies for the treatment of severe sepsis: progress and pitfalls. Proc Nutr SoC 2004, 63(3):437-441.

42. Callery MP, Kamei T, Mangino MJ, Flye MW: Organ interactions in sepsis. Host defense and the hepatic-pulmonary macrophage axis. Arch Surg 1991, 126(1):28-32.

43. Jeschke MG, Klein D, Thasler WE, Bolder U, Schlitt HJ, Jauch KW, Weiss TS: Insulin decreases inflammatory signal transcription factor expression in primary human liver cells after LPS challenge. Mol Med 2008, 14(1-2):11-19.

44. Koo DJ, Chaudry IH, Wang P: Kupffer cells are responsible for producing inflammatory cytokines and hepatocellular dysfunction during early sepsis. J Surg Res 1999, 83(2):151-157.

45. Remick DG, Bolgos G, Copeland S, Siddiqui J: Role of interleukin-6 in mortality from and physiologic response to sepsis. Infect Immun 2005, 73(5):2751-2757.

46. Sun Y, Varambally S, Maher CA, Cao Q, Chockley P, Toubai T, Malter C, Nieves E, Tawara I, Wang $Y$, et al: Targeting of microRNA-142-3p in dendritic cells regulates endotoxin-induced mortality. Blood 2011 117(23):6172-6183.

47. Zeckey C, Hildebrand F, Hoevel P, Muller K, Krettek C, Barkhausen T, van Griensven M: Activity of lymphocyte subpopulations in polymicrobial sepsis and DHEA treatment in IL-6 knockout mice. J Innate Immun 2010, 2(5):469-477.

48. Goldmann O, Chhatwal GS, Medina E: Contribution of natural killer cells to the pathogenesis of septic shock induced by Streptococcus pyogenes in mice. J Infect Dis 2005, 191(8):1280-1286.

49. Pape HC, Remmers D, Grotz M, Schedel I, von Glinski S, Oberbeck R, Dahlweit M, Tscherne H: Levels of antibodies to endotoxin and cytokine release in patients with severe trauma: does posttraumatic dysergy contribute to organ failure? J Trauma 1999, 46(5):907-913.

50. Remick DG: Pathophysiology of sepsis. Am J Pathol 2007. 170(5):1435-1444

51. Osuchowski MF, Welch K, Siddiqui J, Remick DG: Circulating cytokine/inhibitor profiles reshape the understanding of the SIRS/CARS continuum in sepsis and predict mortality. J Immunol 2006, 177(3):1967-1974.

52. Remick DG, Bolgos GR, Siddiqui J, Shin J, Nemzek JA: Six at six: interleukin- 6 measured $6 \mathrm{~h}$ after the initiation of sepsis predicts mortality over 3 days. Shock 2002, 17(6):463-467.

53. Frink M, Van Griensven M, Kobbe P, Brin T, Zeckey C, Vaske B, Krettek C, Hildebrand F: IL-6 predicts organ dysfunction and mortality in patients with multiple injuries. Scand J Trauma Resusc Emerg Med 2009, 17:49.

54. Oberholzer A, Souza SM, Tschoeke SK, Oberholzer C, Abouhamze A, Pribble JP, Moldawer LL: Plasma cytokine measurements augment prognostic scores as indicators of outcome in patients with severe sepsis. Shock 2005, 23(6):488-493.

55. Presterl E, Staudinger T, Pettermann M, Lassnigg A, Burgmann H, Winkler S, Frass M, Graninger W: Cytokine profile and correlation to the APACHE III and MPM II scores in patients with sepsis. Am J Respir Crit Care Med 1997, 156(3 Pt 1):825-832.

56. Remick DG: Cytokine therapeutics for the treatment of sepsis: why has nothing worked? Curr Pharm Des 2003, 9(1):75-82.

57. Landry DW, Levin HR, Gallant EM, Ashton RC Jr, Seo S, D'Alessandro D, Oz MC, Oliver JA: Vasopressin deficiency contributes to the vasodilation of septic shock. Circulation 1997, 95(5):1122-1125.

doi:10.1186/1471-2172-13-59

Cite this article as: Malardo et al.: Low-dose plasmid DNA treatment increases plasma vasopressin and regulates blood pressure in experimental endotoxemia. BMC Immunology 2012 13:59. 